\title{
Local Knowledge on Useful Plants in The Coastal Line Along Parangtritis and its Surroundings
}

\author{
Meri Handayani*, Eka Sulistyowati \\ Department of Biology Education, Fakulty of Science and Technology, UIN Sunan Kalijaga Yogyakarta. \\ J1. Marsda Adisucipto Yogyakarta 55281, DIY. Tel/Fax. +62-87-739092551, \\ Email*: merihand05@gmail.com
}

\begin{abstract}
In the coastal areas of Parangtritis and its surroundings have plant's diversity which is still not much researched and documented. Documentation of the useful plants by local people (ethnobotany) is needed so that knowledge will be exist. This is due to the development of technology and science, the local knowledge about plant is increasingly degraded. This study aims to find out the knowledge and use of plants by local people. Data about plant's diversity was carried out by analyzing vegetation in the coastal areas of Parangtritis and its surroundings which consisted of three locations namely Mangrove Forest of Baros, Parangkusumo Sand Dune, and Karst around Langse Cave. Data collection of ethnobotany was carried out by direct observation and semi-structured interviews with key informants. Snowball sampling technique was used to determine the key informants. The results of the study obtained 40 plant species from 27 families. Among 40 species, there were species that had a single function or others that had multiple function. It divided into 7 usability groups, namely fodder (22 species), medicine (11 species), timber (4 species), household plant (19 species), ritual (2 species), ornamental (6 species), and crafts ( 2 species).
\end{abstract}

Keywords: Coastal of Parangtritis Beach and its surroundings, Ethnobotany, and Useful Plants

\section{INTRODUCTION}

The coastal plants have important ecological functions to maintenance ecosystem such as shade, protection from wind, sand and salt spray, erosion and flood control, coastal reclamation, animal and plant habitats, soil improvement, and their ability to live in harsh coastal environment (Thaman, 1992). On the other hand, coastal areas in tropical countries are rapidly changing due to tourism and urbanization. It causes pressure on natural resources and local people (Ludwinsky and Hanazaki, 2018). Documentation of the useful plants by local people (ethnobotany) is needed so that knowledge will be exist.

The relationship between plants and human cannot be separated. Ethnobotany refers to the field of study that examines the interaction between human societies and the plant kingdom, especially how indigenous people perceive, manage and utilize the plants around them (Radhakrishnan, et al., 2016). Plant's biodiversity provide humans with four categories of ecosystem goods and services which are provisioning, regulating, supporting and cultural services (Maroyi, 2017). According to Khan, et al., 2013, plant in provisioning services to humans are food, fodder, medicines, timber, fuelwood and grazing, ornamental resources, while regulating services include air and water quality and erosion control. Plant species also play a vital role in supporting services such as soil formation, and nutrient and water cycling and in cultural services, including ritual human knowledge systems, recreation and ecotourism, and cultural diversity.

\section{MATERIALS AND METHODS}

The study was conducted in the coastal area of Parangtritis, especially in three locations namely Mangrove Forest of Baros, Parangkusumo Sand Dune, and Karst around Langse Cave. Plants were collected in the field using two belt transect method (size: $1500 \mathrm{~m}^{2}$ ). It's consisted five quadrat plots sized $10 \times 10 \mathrm{~m}^{2}$ for each location. The information collected included the number of species, picture, and record to identify the species. Diversity of species would be calculated by the Shannon Weiner index. Species that have been found were used to collect data of ethnobotany.

Ethnobotanical data were collected by direct observation and semi-structured interviews with key informants. Snowball sampling technique was used to determine the key informants. The information collected included local name, parts used, and uses of the plant. Finally, the data would be anaylized by qualitative descriptive analysis.

\section{RESULTS AND DISCUSSION}

\section{Vegetation Diversity}

The results of the research have been obtained 70 plant species from 33 family with a total of 1,601 individuals. In the Mangrove forest of Baros, there were 13 species from 12 families with 413 individuals. In Parangkusumo Sand Dune obtained 32 species from 17 families with a total of 840 individuals. Whereas in the Karst around Langse Cave, there were 35 species from 23 families 
with a total of 348 individuals. Data on the number of species would be processed to determine the diversity index. In this study use the Shannon-Weinner Diversity Index. The result of the Shannon-Weinner diversity index were 1.68 in mangrove forest of Baros which means moderate vegetation diversity; 2.38 in Parangkusumo Sand Dune which means moderate vegetation diversity; and 3.01 in Karst around Langse Cave which means high vegetation diversity.

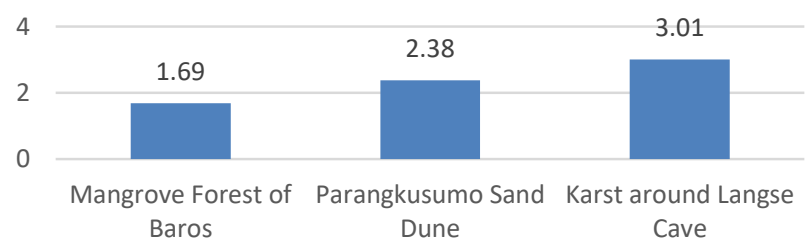

Figure 1. Comparison of the Shannon-Wiener Diversity Index.
Ethnobiological Potential of Local Communities

The results of the study of vegetation diversity found 70 species of plants, but only about 40 species of plants can be utilized by local people. Based on interviews, 40 species of plants consist of 27 families which can be divided into 7 usebility groups, namely fodder (22 species), medicine (11 species), timber (4 species), household plants (19 species), ritual (2 species), ornamental (6 species), and crafts (2 species). Detail the use of plants by the people of Parangtritis Village and its surrounding is presented in table 1 .

Table 1. List of Useful Plants in the Local People.

\begin{tabular}{|c|c|c|c|c|c|c|}
\hline No & Species Name & Family & Local Name & Part Used & Uses of the Plant & Location \\
\hline 1 & Acanthus ilicifolius & Acanthaceae & Jeruju, druju & Leaf, stem, root, fruit & Medicine & MF \\
\hline 2 & Anacardium occidentale & Anacardiaceae & Jambu mete & Leaf & Medicine, food & SD \\
\hline 3 & Calotropis gigantea & \multirow[t]{2}{*}{ Apocynaceae } & Widuri & Sap & Fodder & $\mathrm{SD}, \mathrm{LC}$ \\
\hline 4 & Catharanthus roseus & & Tapak dara & Leaf, flower & $\begin{array}{l}\text { Medicine, } \\
\text { Ornamental }\end{array}$ & $\mathrm{SD}$ \\
\hline 5 & Cocos nucifera & \multirow[t]{2}{*}{ Arecaceae } & Kambil & Leaf, stem, fruit & $\begin{array}{l}\text { Timber, food, } \\
\text { firewood }\end{array}$ & $\mathrm{LC}$ \\
\hline 6 & Borassus flabellifer & & Siwalan & Fruit & Food, craft & SD \\
\hline 7 & Chromolaena odorata & \multirow[t]{4}{*}{ Asteraceae } & Kero & Leaf, stem & Fodder & SD, LC \\
\hline 8 & Wedelia biflora & & - & Leaf & Fodder & $\mathrm{LC}, \mathrm{MF}$ \\
\hline 9 & Tridax procumbens & & Sundel bedel & Leaf & Fodder & SD \\
\hline 10 & Wedelia trilobata & & - & Leaf & Fodder, ornamental & MF \\
\hline 11 & Avicennia sp & Avicenniaceae & Api-api & Fruit & Food & MF \\
\hline 12 & Dolichandrone spathacea & Bignoniaceae & Jaranan & Stem & Fodder, firewood & MF \\
\hline 13 & Casuarina equisetifolia & Casuarinaceae & Cemara & Leaf & Fodder & SD \\
\hline 14 & Calophyllum inophyllum & Clusiaceae & Nyamplung & Fruit & Biogas & SD \\
\hline 15 & Terminalia catappa & Combretaceae & Ketapang & Leaf & $\begin{array}{l}\text { Fodder, timber, } \\
\text { firewood }\end{array}$ & LC, MF \\
\hline 16 & Adiantum Cuneatum & \multirow[t]{2}{*}{ Commelinaceae } & - & Leaf & Ornamental & $\mathrm{LC}$ \\
\hline 17 & Commelina communis & & Pring-pringan & Leaf & Fodder & LC \\
\hline 18 & Ipomea pes-caprae & Convolvulaceae & Katangan & Seed & Medicine & $\mathrm{SD}, \mathrm{MF}$ \\
\hline 19 & Cycas sp & Cycadaceae & Pakis haji & Stem & Ornamental & $\mathrm{LC}$ \\
\hline 20 & Cyperus rotundus & Cyperaceae & Rumput, Suket & Leaf & Fodder & LC \\
\hline 21 & Manihot sp & \multirow[t]{2}{*}{ Euphorbiaceae } & Singkong & Leaf, fruit & Food & SD \\
\hline 22 & Euphorbia heterephylla & & Katemas & Leaf & Fodder & $\mathrm{LC}$ \\
\hline 23 & Acacia auriculiformis & \multirow[t]{3}{*}{ Fabaceae } & Akasia & Leaf, stem & Fodder, timber & SD \\
\hline 24 & Gliricidia sepium & & Leresede & Leaf, stem & Fodder, firewood & LC \\
\hline 25 & Tamarindus indica & & Asem & Leaf, stem ('Galih') & $\begin{array}{l}\text { Medicine, food, } \\
\text { traditiom }\end{array}$ & $\mathrm{LC}$ \\
\hline 26 & Fragraea ceilanica & Gentianaceae & Nyonot & Leaf & Fodder & $\mathrm{LC}$ \\
\hline 27 & Leucas biflora & \multirow[t]{2}{*}{ Lamiaceae } & - & Flower & Ornamental & LC \\
\hline 28 & Premna sp & & - & Leaf & Fodder & $\mathrm{LC}$ \\
\hline 29 & Elaphoglossum sp & Lomariopsidaceae & - & Leaf & Ornamental & $\mathrm{LC}$ \\
\hline 30 & Hibiscus tiliaceus & Malvaceae & Waru & Leaf & Fodder, timber, & MF \\
\hline
\end{tabular}




\begin{tabular}{|c|c|c|c|c|c|c|}
\hline No & Species Name & Family & Local Name & Part Used & Uses of the Plant & Location \\
\hline & & & & & \multicolumn{2}{|l|}{ firewood, wrapper } \\
\hline 31 & Ficus septica & Moraceae & Awar-awar & Leaf & Fodder, medicine & $\mathrm{LC}$ \\
\hline 32 & Moringa oleifera & Moringaceae & Kelor & Leaf, stem & $\begin{array}{l}\text { Fodder, medicine, } \\
\text { firewood }\end{array}$ & $\mathrm{LC}$ \\
\hline 33 & Pandanus sp & Pandanaceae & Pandan & Leaf & Craft, medicine & $\begin{array}{l}\text { SD, MF, } \\
\text { LC }\end{array}$ \\
\hline 34 & Passiflora suberosa & Passifloraceae & - & Leaf & Fodder & LC \\
\hline 35 & Lophatherum gracile & \multirow[t]{3}{*}{ Poaceae } & - & Leaf & Fodder & $\mathrm{MF}$ \\
\hline 36 & $\begin{array}{l}\text { Dactyloctenium } \\
\text { aegyptium }\end{array}$ & & Rumput, Suket & Leaf & Fodder & SD \\
\hline 37 & Cynodon dactylon & & Rumput, Suket & Leaf & Fodder & $\mathrm{LC}$ \\
\hline 38 & Guettarda speciose & \multirow[t]{2}{*}{ Rubiaceae } & & Leaf & Wrapper & LC \\
\hline 39 & Morinda citrifolia & & Pace & Leaf & $\begin{array}{l}\text { Medicine, ritual, } \\
\text { food }\end{array}$ & MF \\
\hline 40 & Cayratia trifolia & Vitaceae & - & Leaf & Fodder & LC \\
\hline
\end{tabular}

Location: LC, Langse Cave; SD, Sand Dune; MF, Mangrove Forest

Based on the table 1, it can be inferred that $33 \%$ of plant utilization by the community is for fodder, $29 \%$ for household plants. While only $3 \%$ were used as ritual and crafts. The percentage of each useful plant category can be seen in figure 2 .

Most part of plant that used by people of Parangtritis and its surroundings is leaf, about $51 \%$. And the least part of plant that used is sap, about $1 \%$. According to Handayani (2015), the high frequency of utilization of leaf parts as a medicinal ingredient is related to several advantages such as the number or productivity of leaves which are more easily obtained compared to other parts and their use is relatively easier because many can be used directly. The percentage of the use of plant organs by the public can be seen in figure 3 .

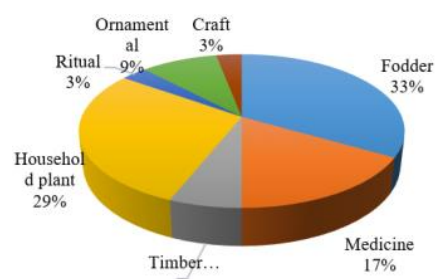

Figure 2. Percentage of Utilization of Plant Species by Local People.

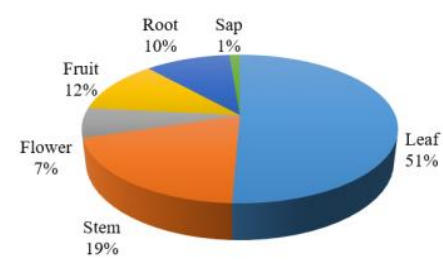

Figure 3. Percentage of plant parts / organs used.

\section{Fodder}

Fodder production and its utilization depend on the cropping pattern, climate, social-economic conditions and type of livestock. The cows and buffaloes are normally fed on fodder available from cultivated areas, supplemented to a small extent by harvested grasses and top feeds (Mishra and Pathak, 2015).

Livestock that are widely cultivated by local people are cows and goats. Based on the results of the study obtained 22 species of fodder from 14 families. The plants most widely used as fodder were from the family Poaceae and Asteraceae.

\section{Medicinal Plant}

Based on the research results obtained 11 species of medicinal plants from 10 families. Species that were used by the local people as medicinal plants were Pandanus sp (pandan), Calotropis gigantea (widuri), Chromolaena odorata (kero), Ficus septica (awar-awar), Tamarindus indica (wit asem), Moringa oleifera (kelor), Acanthus ilicifolius (druju), Ipomea pes-caprae (katangan), Morinda citrifolia (pace), Catharanthus roseus (tapak dara), Anacardium occidentale (jambu mete). Detail of the utilization of medicinal plant is presented in table 2 . 
Table 2. Lists of Species of Medicinal Plants used by Local People.

\begin{tabular}{|c|c|c|c|c|}
\hline No & Species Name & Part Used & Use of Plant & Procedure \\
\hline 1 & Pandanus sp & Stem & Toothache & $\begin{array}{l}\text { Slice the stem, cleaned up, rub slowly on cheek, } \\
\text { toothache located. Tootwhorm will come out through } \\
\text { the pore of cheeks. }\end{array}$ \\
\hline 2 & Calotropis gigantea & Sap & Chapped foot & Smear on chapped foot \\
\hline 3 & $\begin{array}{l}\text { Chromolaena } \\
\text { odorata }\end{array}$ & Leaf & Incision wound & Rub slowly on incision wound \\
\hline 4 & Ficus septica & Leaf & Cold & Steamed leaves, squeezed, drink \\
\hline 5 & Tamarindus indica & Leaf & High blood pressure & Boil the leaves with meat \\
\hline 6 & Moringa oleifera & Leaf & $\begin{array}{l}\text { Diabete millitus, cancer, } \\
\text { vertigo, high blood pressure, } \\
\text { rheumatic pain, etc. }\end{array}$ & Boil \\
\hline 7 & Acanthus ilicifolius & $\begin{array}{l}\text { Root, Leaf, } \\
\text { Fuit, Stem }\end{array}$ & $\begin{array}{l}\text { Diabete millitus, cancer, } \\
\text { vertigo, high blood pressure }\end{array}$ & Fruit or seed boiled, make tea, or eat directly \\
\hline 8 & Ipomea pes-caprae & Seed & A venomous animal bite & Smear on the bitten part \\
\hline 9 & Morinda citrifolia & Fruit, Leaf & High blood pressure & Make juice \\
\hline 10 & $\begin{array}{l}\text { Catharanthus } \\
\text { roseus }\end{array}$ & Leaf & Gout pain & Dry the leaves, then make a tea \\
\hline 11 & $\begin{array}{l}\text { Anacardium } \\
\text { occidentale }\end{array}$ & Leaf & Diarrhea & Eat directly as fresh vegetables \\
\hline
\end{tabular}

\section{Household Plants}

The intended household plants are plants that are useful for household needs such as firewood, food sources, food packages, pesticides, biogas, and fertilizers. Based on the results of the study there were 19 species of plants used for household needs. The biggest utilization of plants as household needs is for food sources $36 \%$, while the least utilization is for fertilizers and pesticides.

Plants that are used as food sources are Tamarindus indica (fruit), Moringa oleifera (leaf), Cocos nucifera (fruit), Manihot sp (tuber), Anacardium occidentale (fruit), Borassus flabellifer (fruit), Avicennia sp (fruit), and Morinda citrifolia (fruit). Fruit is the most plant part /organ used as a food source by the community in Parangtritis Village and its surroundings.

\section{Ornamental Plants}

Ornamental plants are plants that are grown for decorative purposes in gardens and landscape for their beautiful flowers and/or elegant leaves. They are grown for the display of aesthetic features like flowers, leaves, scent, overall foliage texture and fruit (Zhigila, et al., 2015). According to Angriyante (2010), ornamental plants are plants that have their own beauty both on flowers, leaves, stems and so on. Based on the research, there were 6 species of ornamental plants found, namely Leucas biflora, Catharanthus roseus, Wedelia biflora, Elaphoglossum sp, Adiantum Cuneatum, and Cycas sp.

\section{Timber}

Based on the result of study, plants that are used as timber or building materials are large trees that have strong wood. There were 4 species used as building materials, namely Cocos nucifera (coconut), Terminalia catappa (ketapang), Acacia auriculiformis (akasia), and Hibiscus tiliaceus (waru). The favorite and most used tree species in Parangtritis and its surrounding for building materials is Cocos nucifera (kelapa). Coconut wood (glugu) is good to be used to make battens or roof trusses by the local people.

\section{Ritual}

The plant that used for traditional ceremonies in Parangtritis and its surrounding is Morinda citrifolia (pace). The part used is the leaf. The leaves were included in the Wiwiti ceremony (the ceremony when the rice harvest begins) as a complement to offerings made by farmers in Baros. The ceremony was held as a thanksgiving and offering to Dewi Sri (Dewi Padi) for the abundance of rice harvest (Afriyanto, 2013).

In addition, the other ritual plant that considered to have magical powers are Tamarindus indica (wit asem). The part used is the heart of the tamarind tree in the middle of the trunk called the galih. According to local people belief, this galih of tamarind can be used as a talisman / heirloom / 'aji-aji' that brings lucky and body strength.

\section{Craft}

Plants that used for crafts by the people of Parangtritis and its surroundings, namely Pandanus sp. Most of people who use this plant are people from Pandak District, Bantul. The people uses pandanus leaves to make woven crafts such as bags, hats, mats, and so on. Pandanus that they can come from the coast and even some people cultivate this plant as raw material for making these crafts. 


\section{CONCLUSION}

The diversity of plants in coastal Parangtritis and its surrounding consist 70 species of plants, but only about 40 species of plants can be utilized by local people. As many as 40 species of plants consist of 27 families which can be divided into 7 usability groups, namely fodder (22 species), medicine (11 species), timber (4 species), household plants (19 species), ritual (2 species), ornamental (6 species), and crafts (2 species). Most of the plants that people use come from the Langse Cave. This is relevant to the results of the calculation of the Shannon-Weinner Diversity Index, that the highest diversity was found in Langse Cave.

\section{ACKNOWLEDGEMENTS}

The authors wish to thank to Eka Sulistyowati as lecturer and mentor, Yatini, Sindi Farhana, Nisa Ulmah Mudah, and any friends who accompanied and supported the research.

\section{REFERENCES}

Afriyanto. 2013. Wiwit, Sebuah Tradisi Menjelang Panen Padi. Yogyakarta. Universitas Widya Mataram.

Angriyantie, Liana. 2010. Etnobotani dan Potensi Tumbuhan Berguna di Kampung Keay, Kabupaten Kutai Barat,
Kalimantan Timur. Bogor: Fakultas Kehutanan Institut Pertanian Bogor.

Handayani, Aisyah. 2015. Pemanfaatan tumbuhan berkhasiat obat oleh masyarakat sekitar Cagar Alam Gunung Simpang, Jawa Barat. Pros Sem Nas Masy Biodiv Indon. 1: 1425-1432.

Khan SM, Page SE, Ahmad H, Harper DM. 2013. Sustainable Utilization and Conservation of Plant Biodiversity in Montane Ecosystems: the western Himalayas as a case study. Annals of Botany.112:479-501.

Ludwinsky, Rafaela H. and Natalia Hanazaki. 2018. Ethnobotany in a coastal environmental protected area: shifts in plant use in two communities in southern Brazil. Journal of Ethnobiology and Ethnomedicine. 14: 1-10.

Maroyi, Alfred. 2017. Diversity of use and local knowledge of wild and cultivated plants in the Eastern Cape province, South Africa. Journal of Ethnobiology and Ethnomedicine. 13: 1-16.

Mishra, Seema and P. S. Pathak. 2015. Fodder Production and Conservation: A Potential Source of Livelihood for Women. New Delhi: Narosa Publishing House

Radhakrishnan, K., M. Navas, Vinodkumar T G Nair, S. Rajasekharan, Suresh Kumar P., and Smith Simon. 2016. Ethnobotanical Survey in the Coastal Areas of Thiruvananthapuram District, Kerala. Journal Ritualal and Folk Practices. 1: 193-196.

Thaman, R.R. 1992. Batiri Kei Baravi: The Ethnobotany of Pacific Island Coastal Plants. Washington: Atoll Research Bulletin.

Zhigila, Daniel Andrawus, Fatima B. Jafun Sawa, Felix Ayodele Oladele, and Sulaiman Muhammad. 2015. Aesthetic Values and Significance of Ferns to Landscaping Industries - A Taxonomic Review. International Journal of Current Research in Biosciences and Plant Biology.2: 7-13. 
THIS PAGE INTENTIONALLY LEFT BLANK 